\title{
Tear glucose levels in normal people and in diabetic patients
}

\author{
D. K. SEN AND G. S. SARIN \\ From the Department of Ophthalmology, Maulana Azad Medical College, \\ Lok Nayak Jai Prakash Narain Hospital, and Guru Nanak Eye Centre, New Delhi, India
}

SUMMARY Fifty normal people and 50 diabetic patients were studied by means of an enzymatic method for the glucose content in the blood, tears, and urine before and after the peroral glucose load. In normal subjects the fasting glucose lo vels in the tears averaged $3.6 \mathrm{mg} / 100 \mathrm{ml}(0.2 \mathrm{mmol} / \mathrm{l})$ and in the diabetic patients it averaged $16.6 . \mathrm{ng} / 100 \mathrm{ml}(0.92 \mathrm{mmol} / \mathrm{l})$. As in blood and urine, tear glucose levels are significantly higher in diabetic patients than normal persons both at fasting and after the peroral glucose load test. The fasting tear glucose level did not appear to be a satisfactory index for classifying a person as a diabetic or normal. It was found that after the peroral glucose load test a tear glucose level at $11 \mathrm{mg} / 100 \mathrm{ml}(0.61 \mathrm{mmol} / \mathrm{l})$ resulted in only $4.6 \%$ of the diabetics being missed, while $5 \cdot 8 \%$ of the normal persons were misclassified as diabetics.

It has been the practice to obtain blood or urine samples for glucose analysis to detect hyperglycaemia and diabetes mellitus. Collection of a blood sample is not always convenient and of a urine sample is messy. The difficulties are greater in mass surveys for detecting the prevalence of diabetes in a given population. Attention has therefore been drawn to the study of tear glucose to find out if it can be used as an alternative method for the detection of diabetes and hyperglycaemia, However, the data concerning its level in tears remain confusing and contradictory both as regards its normal level in tears and its relationship with hyperglycaemia..$^{1-4}$

The purpose of this project was to study the relationship between tear glucose and blood glucose in normal people and in diabetic patients before and after the peroral glucose load test. It was also intended to see whether any value of tear glucose could be used to separate diabetics and normal persons.

\section{Patients and methods}

Fifty cases of diabetes mellitus attending the Diabetic Clinic of Lok Nayak Jai Prakash Narain Hospital, New Delhi, with no detectable ocular changes were entered into this study. Their mean

Correspondence to Dr D. K. Sen, V/4, Maulana Azad Medical College Campus, Kotla Road, New Delhi-110002, India. age was 53.9 years (range 27 to 70 years). There were 32 males (mean age $47 \cdot 3$ years, range 27 to 66 years) and 18 females (mean age 56.7 years, range 40 to 70 years).

Fifty healthy people (mean age $41 \cdot 7$ years, range 22 to 75 years) who reported to the Outpatient Department of Guru Nanak Eye Centre, New Delhi, for refraction were entered as controls. There were 35 males (mean age 44.2 years, range 22 to 75 years) and 15 females (mean age $37 \cdot 1$ years, range 26 to 44 years).

Samples of blood, tears, and urine were collected after overnight fast and without the diabetic patients receiving any antidiabetic drugs. Tear specimens were collected by the method already described. ${ }^{5}$ All the samples were stored at $-20^{\circ} \mathrm{C}$ and analysed on the same day. An oral load of $100 \mathrm{~g}$ of glucose was given to each subject. Further samples of blood, tears, and urine were collected 2 hours after the peroral glucose load test. The samples were analysed by the enzymatic method. ${ }^{6}$

\section{Results}

The mean, standard deviation, and coefficient of variation (CV) of the level of glucose in blood, tears, and urine in normal persons and in diabetic patients during fasting and after the glucose load are given in Table 1. It can be seen that there was considerable variation from one individual to another in fasting glucose level and the level after 
Table 1 Blood, tear, and urine glucose in $\mathrm{mg} / 100 \mathrm{ml}$ in normal subjects and in diabetic patients

\begin{tabular}{|c|c|c|c|c|c|c|c|c|c|c|c|c|c|c|c|}
\hline & \multicolumn{5}{|l|}{ Blood } & \multicolumn{5}{|l|}{ Tears } & \multicolumn{5}{|l|}{ Urine } \\
\hline & \multicolumn{2}{|l|}{ Fasting } & \multicolumn{2}{|c|}{ Peroral load } & \multirow{2}{*}{$\begin{array}{l}\text { Mean } \\
\text { rise } \\
(\%)\end{array}$} & \multicolumn{2}{|l|}{ Fasting } & \multicolumn{2}{|c|}{ Peroral load } & \multirow{2}{*}{$\begin{array}{l}\text { Mean } \\
\text { rise } \\
(\%)\end{array}$} & \multicolumn{2}{|l|}{ Fasting } & \multicolumn{2}{|c|}{ Peroral load } & \multirow{2}{*}{$\begin{array}{l}\text { Mean } \\
\text { rise } \\
(\%)\end{array}$} \\
\hline & $\begin{array}{l}\text { Mean } \pm \\
S D\end{array}$ & $\begin{array}{l}C V \\
(\%)\end{array}$ & $\begin{array}{l}\text { Mean } \pm \\
S D\end{array}$ & $\begin{array}{l}C V \\
(\%)\end{array}$ & & $\begin{array}{l}\text { Mean } \pm \\
S D\end{array}$ & $\begin{array}{l}C V \\
(\%)\end{array}$ & $\begin{array}{l}\operatorname{Mean} \pm \\
S D\end{array}$ & $\begin{array}{l}C V \\
(\%)\end{array}$ & & $\begin{array}{l}\text { Mean士 } \\
S D\end{array}$ & $\begin{array}{l}C V \\
(\%)\end{array}$ & $\begin{array}{l}\text { Mean } \pm \\
S D\end{array}$ & $\begin{array}{l}C V \\
(\%)\end{array}$ & \\
\hline Diabetics & $\begin{array}{c}168 \cdot 2 \pm \\
61 \cdot 8\end{array}$ & $36 \cdot 7$ & $\begin{array}{c}280 \cdot 1 \\
81 \cdot 6\end{array} \pm$ & $29 \cdot 1$ & $66 \cdot 5$ & $\begin{array}{c}16 \cdot 6 \pm \\
9 \cdot 4\end{array}$ & 56.6 & $\begin{array}{l}43 \cdot 1 \pm \\
19 \cdot 1\end{array}$ & $44 \cdot 3$ & 159.6 & $\begin{array}{l}44 \cdot 8 \pm \\
49 \cdot 1\end{array}$ & $109 \cdot 5$ & $\begin{array}{c}138.6 \pm \\
89.8\end{array}$ & $64 \cdot 7$ & $209 \cdot 4$ \\
\hline Normals & $\begin{array}{l}76 \cdot 5 \pm \\
10 \cdot 3\end{array}$ & 13.4 & $\begin{array}{c}107 \cdot 6 \pm \\
18 \cdot 3\end{array}$ & $17 \cdot 0$ & $40 \cdot 6$ & $\begin{array}{l}3 \cdot 6 \pm \\
2 \cdot 6\end{array}$ & $72 \cdot 2$ & $\begin{array}{l}6 \cdot 0 \pm \\
3 \cdot 2\end{array}$ & $53 \cdot 3$ & $66 \cdot 7$ & $\begin{array}{l}6 \cdot 0 \pm \\
3.7\end{array}$ & $61 \cdot 6$ & $\begin{array}{c}14.5 \pm \\
5 \cdot 8\end{array}$ & $40 \cdot 0$ & $141 \cdot 7$ \\
\hline
\end{tabular}

SI conversion: $\mathrm{mmol} / \mathrm{l}=\mathrm{mg} / 100 \mathrm{ml} \times 0.0555$.

the glucose load in blood, tears, and urine both in normals and diabetics. The mean fasting level of glucose in blood, tears, and urine in diabetics was significantly higher $(P<0.001)$ than in normal persons. There was no significant correlation between glucose content of blood and tears among normal persons and diabetics (normals: $r=0 \cdot 17$, for $48 \mathrm{DF} P \gg 0 \cdot 10$; diabetics: $r=-0.03$, for $48 \mathrm{DF}$ $P \gg 0 \cdot 10$ ). A significant rise of glucose level after the glucose load was found in blood, tears, and urine both in normal persons and in diabetics. The mean percentage rise of glucose level in blood, tears, and urine after the glucose load was more in diabetics. The mean percentage rise in the glucose level in tears was more than the percentage rise in blood after the glucose load in diabetic subjects.

On the assumption of a normal distribution an estimate was made of the proportion of diabetics who would be wrongly classified if a particular glucose level in tears and in urine was considered to seperate the 2 groups.

\section{TEARS}

Tables 2 and 3 show the percentage of subjects misclassified with different critical levels of fasting glucose and those after the glucose load. Whereas the fasting glucose level did not appear to be satisfactory for the purpose of classification into diabetics and normal persons, very good results were obtained when the glucose level after the glucose load are considered. For example, with the level of glucose at $11 \mathrm{mg} / 100 \mathrm{ml}(0.61 \mathrm{mmol} / \mathrm{l})$ only $4.6 \%$ of the diabetics and $5.8 \%$ of the normals would be wrongly classified (Table 3).

\section{URINE}

None of the glucose values in fasting samples were found to be satisfactory for the purpose of classification into diabetics and normal persons (Table 4). The percentage of diabetics misclassified as normal was too high for all the levels considered, namely, 10 to $17 \mathrm{mg} / 100 \mathrm{ml}(0.56$ to $0.94 \mathrm{mmol} / \mathrm{l})$. When the values lower than $10 \mathrm{mg} / 100 \mathrm{ml}(0.56 \mathrm{mmol} / \mathrm{l})$ were
Table 2 Misclassification with different critical levels ( $\mathrm{mg} / 100 \mathrm{ml}$ ) of fasting tear glucose level

\begin{tabular}{|c|c|c|c|c|c|c|c|}
\hline & \multicolumn{7}{|c|}{ Percentage misclassified at level } \\
\hline Diabetics & $9 \cdot 0$ & 10.9 & $12 \cdot 9$ & $15 \cdot 4$ & $18 \cdot 1$ & $20 \cdot 9$ & $24 \cdot 2$ \\
\hline Normals & $44 \cdot 4$ & $30 \cdot 2$ & $18 \cdot 7$ & $10 \cdot 2$ & $5 \cdot 0$ & $2 \cdot 1$ & $0 \cdot 8$ \\
\hline
\end{tabular}

SI conversion: $\mathrm{mmol} / \mathrm{l}=\mathrm{mg} / 100 \mathrm{ml} \times 0.0555$.

Table 3 Misclassification with different critical levels $(\mathrm{mg} / 100 \mathrm{ml})$ of tear glucose after peroral glucose load

\begin{tabular}{lrrrrrrrrr}
\hline \multicolumn{8}{c}{ Percentage } \\
& 10 & 11 & 12 & 13 & 14 & 15 & 16 & 17 \\
\hline Diabetics & 4.2 & 4.6 & 5.2 & 5.7 & 6.4 & 7.1 & 7.8 & 8.5 \\
Normals & 10.4 & 5.8 & 3.0 & 1.4 & 0.6 & 0.2 & 0.1 & 0.0 \\
\hline
\end{tabular}

SI conversion: $\mathrm{mmol} / \mathrm{l}=\mathrm{mg} / 100 \mathrm{ml} \times 0.0555$.

Table 4 Misclassification with different critical level $(\mathrm{mg} / 100 \mathrm{ml})$ of fasting urine glucose

\begin{tabular}{lrrrrrrrr}
\hline \multicolumn{10}{c}{ Percentage misclassified at level } \\
& 10 & \multicolumn{1}{c}{11} & \multicolumn{1}{c}{12} & \multicolumn{1}{c}{13} & \multicolumn{1}{c}{14} & \multicolumn{1}{c}{15} & \multicolumn{1}{c}{16} & \multicolumn{1}{c}{17} \\
\hline Diabetics & 23.9 & 24.5 & 25.1 & 25.8 & 26.4 & $27 \cdot 1$ & 27.8 & 28.4 \\
Normals & 13.6 & 8.5 & 5.0 & 2.7 & 1.4 & 0.7 & 0.3 & 0.1 \\
\hline
\end{tabular}

SI conversion : $\mathrm{mmol} / \mathrm{l}=\mathrm{mg} / 100 \mathrm{ml} \times 0.0555$.

Table 5 Misclassification with different critical levels ( $\mathrm{mg} / 100 \mathrm{ml}$ ) of urine glucose after peroral glucose load

\begin{tabular}{lllllllll}
\hline \multicolumn{8}{c}{ Percentage misclassified at level } \\
& 24 & 25 & 26 & 27 & 28 & 29 & 30 & 31 \\
\hline Diabetics & 7.5 & 7.6 & 7.9 & 8.1 & 8.2 & 8.4 & 8.5 & 8.7 \\
Normals & 9.0 & 6.9 & 5.3 & 3.9 & 2.9 & 2.1 & 1.5 & 1.0 \\
\hline
\end{tabular}

SI conversion : $\mathrm{mmol} / \mathrm{l}=\mathrm{mg} / 100 \mathrm{ml} \times \mathbf{0 . 0 5 5 5}$.

considered, the percentage of normal persons misclassified as diabetic were unacceptably high. However, the glucose levels after the glucose load are more satisfactory (Table 5). For example, with 
a critical value of $26 \mathrm{mg} / 100 \mathrm{ml}(1.44 \mathrm{mmol} / \mathrm{l})$ only $7.9 \%$ of the diabetics and $5.3 \%$ of the normals would be wrongly classified.

\section{Discussion}

Several workers have studied the glucose level in tears in normal subjects (Ridley ${ }^{1}-65 \mathrm{mg} / 100 \mathrm{ml}$ (3.6 mmol/l), Borsellino ${ }^{7}-27 \mathrm{mg} / 100 \mathrm{ml}(1.5$ $\mathrm{mmol} / \mathrm{l})$, Giardini and Roberts ${ }^{2}-2.6 \mathrm{mg} / 100 \mathrm{ml}$ $(0.14 \mathrm{mmol} / \mathrm{l})$ Gasset et al. ${ }^{3}-4.1 \mathrm{mg} / 100 \mathrm{ml}(0.23$ $\mathrm{mmol} / \mathrm{l})$, and Motoji $\left.{ }^{8}-7.2 \mathrm{mg} / 100 \mathrm{ml}(0.4 \mathrm{mmol} / \mathrm{l})\right)$. In our study it averaged $3.6 \mathrm{mg} / 100 \mathrm{ml}(0.2 \mathrm{mmol} / \mathrm{l})$ in normal subjects.

Michail et al. ${ }^{9}$ first demonstrated in 1937 the rise of tear glucose during hyperglycaemia (alimentary and diabetic). Lewis and Stephens ${ }^{4}$ and Giardini ${ }^{10}$ studied the level of tear glucose in diabetic patients and found it to be often raised, though the increase bore no relationship to blood glucose. Gasset et al. ${ }^{3}$ and Motoji ${ }^{8}$ found a definite relationship of tear glucose and blood glucose and concluded that hyperglycaemia could be detected by measuring tear glucose level. However, in the present study, no significant correlation was found between the glucose level of blood and tears.

Gasset et al..$^{3}$ measured changes in the tear glucose level following oral glucose load and found an increase in the tear glucose level in diabetic patients but no significant rise in the tear glucose level in normal subjects. Motoji ${ }^{8}$ also studied the glucose level in tears in normal subjects and in diabetics before and after peroral glucose load. He found that, while the glucose level in the tears tended to run parallel with the blood glucose level, the former tended to be higher for the same blood glucose level after the peroral glucose load. In our study the mean percentage rise in the level of tear glucose after the peroral glucose load was more than the mean percentage rise in the level of blood glucose both in normal persons and in diabetics, but it was found to be higher in the latter.

Since it was found that, after the glucose load, tear glucose level at $11 \mathrm{mg} / 100 \mathrm{ml}(0.61 \mathrm{mmol} / \mathrm{l})$ was a reliable guide for classifying a person as diabetic, tear glucose levels in the postprandial phase or after giving oral glucose load can be used as a screening device for picking up diabetic cases. Subjects with values higher than $12 \mathrm{mg} / 100 \mathrm{ml}(0.67 \mathrm{mmol} / \mathrm{l})$ could be labelled as diabetics. Subjects with levels between $9 \mathrm{mg} / 100 \mathrm{ml}(0.5 \mathrm{mmol} / \mathrm{l})$ and $12 \mathrm{mg} / 100$ $\mathrm{ml}(0.67 \mathrm{mmol} / \mathrm{l})$ could be considered suspicious and subjected to detailed blood glucose analysis.

This finding can be taken advantage of in surveying the prevalence of diabetes in a population. Persons without diabetic symptoms would be less reluctant to give samples of tears than of blood. Thus a fairly accurate estimate of the prevalence of diabetics could be made with less resistance from the public.

Thanks are due to Mr G. P. Mathur, New Delhi Tuberculosis Centre, for the help in the statistical analysis of our data.

\section{References}

${ }^{1}$ Ridley $F$. The intraocular pressure and drainage of the aqueous humour. Br J Exp Pathol 1930; 11 : 217-40.

${ }^{2}$ Giardini A, Roberts JRE. Concentration of glucose and total chlorides in tears. Br J Ophthalmol 1950; 34: 737-45.

${ }^{3}$ Gasset AR, Braverman LE, Fleming MC, Arky RA, Alter BR. Tear glucose detection of hyperglycaemia. Am J Ophthalmol 1968; 65: 414-20.

${ }^{4}$ Lewis JG, Stephens PJ. Tear glucose and diabetes. $B r J$ Ophthalmol 1958; 42: 754-8.

${ }^{5}$ Sen DK, Sarin GS, Mani K, Saha K. Immunoglobulins in tears of normal Indian people. Br J Ophthalmol 1976; 60: 302-4.

${ }^{6}$ Huggett A st G, Nixon DA. Use of glucose oxidase, peroxidase, and $o$-dianisidine in determination of blood and urinary glucose. Lancet 1957; ii: 368-70.

${ }^{7}$ Borsellino G. Cited by Giardini A, Roberts JRE. Concentration of glucose and total chloride in tears. BrJ Ophthalmol 1950; 34: 737-45.

${ }^{8}$ Motoji K. The glucose content of tear fluid in normal and diabetic subjects. Jpn J Clin Ophthalmol 1971 ; 25: 1945-50. ${ }^{9}$ Michail D, Vancea P, Zolog N. Sur l'élimination lacrymale du glucose chez les diabétiques. C R Soc Biol (Paris) 1937; 125: 1095-9.

${ }^{10}$ Giardini A. Recherches sur les taux de glucose dans les larmes chez les sujets normaux et diabetiques. Boll Oculist 1948; 27 : 585-99. 